\title{
Effect of the northern quahog Mercenaria mercenaria on the development of blooms of the brown tide alga Aureococcus anophagefferens
}

\author{
Robert M. Cerrato ${ }^{1, *}$, David A. Caron ${ }^{2}$, Darcy J. Lonsdale ${ }^{1}$, Julie M. Rose ${ }^{2}$, \\ Rebecca A. Schaffner ${ }^{2}$ \\ ${ }^{1}$ Marine Sciences Research Center, Stony Brook University, Stony Brook, New York 11794-5000, USA \\ ${ }^{2}$ Department of Biological Sciences, 3616 Trousdale Parkway, AHF 301, University of Southern California, \\ Los Angeles, California 90089-0371, USA
}

\begin{abstract}
Three experiments were carried out in 3001 mesocosms using natural seawater from the Peconic Bays ecosystem, Long Island, New York, to examine the ability of the northern quahog Mercenaria mercenaria to prevent blooms of the brown tide alga Aureococcus anophagefferens. Nutrient enrichment and mixing of the mesocosms was conducted according to previous methods that we have employed to induce brown tides. Treatments with and without clams were examined. Abundances of $A$. anophagefferens increased dramatically during 8 to $9 \mathrm{~d}$ experiments in mesocosms without bivalves (average peak abundances $>600000$ cells $\mathrm{ml}^{-1}$ ). The brown tide alga constituted $>50 \%$ of the total phytoplankton biomass in these mesocosms by the end of the experiment. In contrast, algae in mesocosms with high abundances of clams did not develop brown tides and A. anophagefferens abundances in these mesocosms were 2 orders of magnitude lower. Bivalves not only prevented a buildup of total phytoplankton biomass but also prevented the shift in phytoplankton species composition to dominance by $A$. anophagefferens observed in treatments without clams. Experiments to test the efficacy of different abundances of clams for preventing blooms of $A$. anophagefferens demonstrated that population clearance rates by clams of approximately $40 \%$ of the mesocosm volume $\mathrm{d}^{-1}$ were sufficient to prevent the buildup of phytoplankton biomass and net population growth of the brown tide alga under the environmental conditions and nutrient enrichment that we employed. This turnover rate by suspension-feeding bivalves is similar to the same magnitude of bivalve filtration pressure estimated for Great South Bay, Long Island more than 2 decades ago, prior to the outbreak of brown tides. We conclude that the feeding activities of northern quahogs in shallow bays can exert considerable control on total phytoplankton biomass in the overlying water column, and specifically on the ability of $A$. anophagefferens to dominate the phytoplankton assemblage and form brown tides.
\end{abstract}

KEY WORDS: Mercenaria mercenaria · Aureococcus anophagefferens $\cdot$ Brown tide $\cdot$ Phytoplankton · Microzooplankton · Grazing pressure

Resale or republication not permitted without written consent of the publisher

\section{INTRODUCTION}

Recent reports summarizing the global occurrence of outbreaks of harmful algal blooms (HABs) in coastal ecosystems have indicated an increased prevalence of blooms by toxic, noxious or nuisance phytoplankton species in recent years (Anderson 1989, Smayda 1989,
Anderson 1997). Most explanations for these events, and most research that has been conducted to date to examine their causes and prevention, have stressed 'bottom-up' processes (Anderson \& Garrison 1997). This explanation implicates circumstances (whether natural or human-induced) that have lead to increased availability to phytoplankton of macro- or micronutri- 
ents in coastal waters and to a general pattern of increased algal growth in these ecosystems.

Growth of an algal population is certainly required for it to reach bloom conditions in nature but it is not the only prerequisite. Differences among species in their mortality rates can play an equally important role in determining species success or failure in the plankton (Gobler et al. 2002). A rapidly growing alga will not attain bloom conditions if its summed losses (e.g. grazing, parasitism, disease, and advective and sinking losses) are equivalent to its growth rate. Indeed, it is the net growth rate of a phytoplankter relative to the net growth rates of competing species that determine whether or not an alga will increase in biomass and become a dominant species in a natural assemblage of phytoplankton. Recognition of the potential importance of mortality has initiated studies to examine this parameter as both an explanation for increased occurrences of HABs and as a means of predicting and perhaps preventing future HAB events.

Harmful algal blooms called 'brown tides' have occurred in coastal waters of the mid-Atlantic US since 1985 . These blooms have been caused by a minute $(\approx 2$ to $4 \mu \mathrm{m})$, pelagophyte alga described as Aureococcus anophagefferens (Sieburth et al. 1988, Andersen et al. 1993). Brown tides have caused significant environmental damage and economic loss, especially in Long Island waters (Bricelj \& Lonsdale 1997). Although not acutely toxic, populations of economically valuable bivalve molluscs (most notably scallops) were severely affected by high abundances of $A$. anophagefferens, because the feeding activities of these species and other bivalves ceased during blooms of the alga (Bricelj \& Malouf 1984, Tracey 1988, Bricelj \& Kuenstner 1989). A narcotic effect of the alga has been described (Gainey \& Shumway 1991) and 'threshold' abundances that cause cessation of feeding have been documented (Bricelj et al. 2001). The specific agent has not been characterized. In addition to direct effects on bivalves, eelgrass Zostera marina habitats were significantly reduced by the 1985 bloom due to light attenuation by the alga in the water overlying the eelgrass beds (Dennison et al. 1989).

To date, most studies of brown tides have focused on identifying specific factors or environmental conditions that might selectively stimulate the growth of Aureococcus anophagefferens in natural assemblages of phytoplankton, thereby allowing it to simply outgrow its competitors. Numerous scenarios and specific growth factors have been proposed as possible 'causative agents' for these blooms including general eutrophication, increased availability of iron, urea, selenium or DON, or specific meteorological conditions or groundwater input (Cosper et al. 1993, Gobler \& Cosper 1996, Lomas et al. 1996, Berg et al. 1997, LaRoche et al. 1997, Gobler \& Sañudo-Wilhelmy 2001). These studies have provided valuable information relating to the growth requirements of $A$. anophagefferens, but they have not provided a predictive understanding of brown tides. Moreover, this work has indicated that $A$. anophagefferens appears to grow at a slow-to-moderate rate relative to many other minute phytoplankton species (Cosper et al. 1989a, Caron et al. in press). It is difficult to reconcile this modest growth rate (even under optimal conditions) with the alga's ability to attain abundances far in excess of all other phytoplankton solely on the basis of its absolute growth rate. Thus, the explanation for the success of $A$. anophagefferens does not appear to lie exclusively in the factors that might stimulate the growth of the alga, but also in the loss processes removing its competitors.

We have examined an alternative hypothesis to explain the occurrence of brown tides in Long Island waters that involves the interaction between benthic suspension-feeding communities and phytoplankton. Our work is predicated on the observation that stocks of commercially valuable species of bivalves such as northern quahogs Mercenaria mercenaria in embayments around Long Island are a small fraction of stocks estimated to have been present 2 or 3 decades ago (Kassner 1993). A logical expectation is that pelagic food web structure has shifted in response to reductions in the abundances of bivalves (Newell 1988). Nano-, micro- and mesozooplankton species (which should be more abundant with reduced bivalve populations) display considerable feeding selectivity, consuming preferred species of algae and rejecting less desirable species (Stoecker et al. 1986, Burkill et al. 1987, Wiadnyana \& Rassoulzadegan 1989, Jürgens \& Demott 1995, Flynn et al. 1996, Strom \& Loukos 1998, Griffin \& Rippingale 2001). Thus, less desirable species of phytoplankton may experience lower predation rates and these phytoplankton may be assumed to include less nutritious, noxious or toxic algal taxa. In support of this argument, poor nutritional quality and exopolymer excretions have been demonstrated as factors contributing to the dominance of the Texas brown tide alga Aureoumbra lagunensis in Laguna Madre, Texas (Buskey et al. 1997, Liu \& Buskey 2000).

Although not specifically a causative agent of brown tides, lower bivalve abundances may shift pelagic community structure, whereby Aureococcus anophagefferens could dominate the phytoplankton assemblage. Conversely, if populations of bivalves are abundant, they may stabilize pelagic food web structure in a manner that would prevent dominance of $A$. anophagefferens under conditions which otherwise might allow its proliferation. Our experimental work has been an attempt to test that hypothesis.

In previous studies, we devised an experimental mesocosm approach in which Aureococcus anopha- 
gefferens populations increased dramatically, producing a phytoplankton assemblage strongly dominated by $A$. anophagefferens (unpubl. data, Schaffner 1999). This approach allowed us to test (and discard) several hypotheses concerning the ability of nutrient enrichment (general nutrient loading and specific growth factors such as urea and iron) to specifically stimulate net population growth of $A$. anophagefferens. While nutrient loading was a factor controlling the magnitude of the phytoplankton bloom occurring in our mesocosms, the nature of the nutrient (i.e. inorganic nitrogen vs organic nitrogen) did not appear to play an important role in specifically stimulating the growth of A. anophagefferens (unpubl. data, Schaffner 1999). Surprisingly, that work led to the conclusion that mechanical stirring by means of the submersible aquarium pumps (in the absence of Mercenaria mercenaria) is the one factor that leads to situations in which the brown tide alga becomes a dominant species within the phytoplankton assemblages in these mesocosms (unpubl. data, Schaffner 1999).

These experimental studies also indicated an ability of Mercenaria mercenaria to prevent blooms of Aureococcus anophagefferens and prevent a shift in the species composition of the phytoplankton community to dominance by $A$. anophagefferens when clams were present at high abundance. The number of clams in these experiments was equivalent to a natural density of approximately 53 to 105 clams $\mathrm{m}^{-2}$ of seafloor. These densities are high, but possible for natural, unimpacted populations of $M$. mercenaria. They are, however, considerably greater than present standing stocks of this species in Long Island estuaries (Cerrato \& Wallace 1989), suggesting a need to conduct experiments at lower densities.

In the present study, we recreated the conditions leading to dominance of Aureococcus anophagefferens in mesocosms at a different study site, reestablished the importance of Mercenaria mercenaria for preventing a buildup of phytoplankton biomass and/or a shift in phytoplankton species composition, and we conducted experiments to examine the relationship between the density of clams, phytoplankton biomass and the development of brown tides. Abundances of clams in our experiments were equivalent to $0,7,14$, 28, 56 and 67 clams $\mathrm{m}^{-2}$, providing a range of treatments that allowed us to determine the density of $M$. mercenaria necessary to prevent the development of a brown tide.

\section{MATERIALS AND METHODS}

Study site. All experiments were carried out at the Suffolk County Marine Environmental Learning Cen- ter (SCMELC), Southold, NY, located on the northern shore of the Peconic Bays estuary system. This system is a series of connected embayments formed by the northern and southern forks of the eastern end of Long Island. These embayments vary widely in their circulation patterns, nutrient regimes and susceptibility to algal blooms (Cosper et al. 1989b). A major bloom occurred in the Peconic Bays in 1985 and isolated bays (e.g. West Neck Bay, Shelter Island) have remained recurrent 'hot spots' for brown tides since that time (Bricelj \& Lonsdale 1997). The SCMELC is located on a small inlet (Cedar Creek) along the northern boundary of the Peconic Bays. Three experiments were carried out during late May and early June of 2000 (Expt 1) and 2001 (Expts 2 and 3).

Experimental design. The design and performance of the experiments was based on a setup that we have employed previously (Schaffner 1999). All studies were conducted using 300 l cylindrical, translucent polyethylene tanks as mesocosms (Nalgene ${ }^{\circledR}$ i inside diameter of $60 \mathrm{~cm}$ and depth of $122 \mathrm{~cm}$ ). All mesocosms were soaked overnight with $10 \% \mathrm{HCl}$ and rinsed with seawater from Cedar Creek prior to each experiment. All experiments were performed in batch mode (i.e. no exchange) and acidified at the end of each experiment to eliminate any chance of stimulating a brown tide in Cedar Creek. The mesocosms were filled for each experiment by pumping approximately $280 \mathrm{l}$ of natural, unfiltered seawater from Cedar Creek at a depth of $0.5 \mathrm{~m}$ and $10 \mathrm{~m}$ from the shore into each mesocosm. All mesocosms were filled simultaneously to ensure replicability among the treatments.

The abundance of Aureococcus anophagefferens at the beginning of all 3 experiments in the seawater at our study site was near or below the limit of detection of our method (<5000 cells ml ${ }^{-1}$ ) (Caron et al. 2003). In order to begin each experiment with low but measurable populations of brown tide cells in the mesocosms, seawater was collected in acid-washed containers for use as an inoculum. Water for the experiments was collected from Great South Bay, NY. At the time of the experiment in 2000, the abundance of A. anophagefferens in Great South Bay exceeded $10^{6}$ cells $\mathrm{ml}^{-1}$. Abundances during Expts 2 and 3 in 2001 were 2.4 to $4.5 \times 10^{5}$ cells $\mathrm{ml}^{-1}$.

Water temperature in the mesocosms was maintained near ambient by placing all mesocosms into an enclosure (5.5 m diameter holding tank) through which water from Cedar Creek was continually pumped (approx. $4001 \mathrm{~min}^{-1}$ ) for the duration of each experiment. This flow rate maintained the temperature of the mesocosms within $1^{\circ} \mathrm{C}$ of the temperature of Cedar Creek. Mesocosm placement in the enclosure was randomized. Water in the mesocosms was mixed continuously by means of small $(<10 \mathrm{~cm})$, submersible 
aquarium pumps with plastic impellers (Rio Mini 180, TAAM). The pumps were suspended 5 to $10 \mathrm{~cm}$ below the water surface and ran continuously for the duration of each experiment. The pumps circulated water at a rate of approximately $450 \mathrm{l} \mathrm{h}^{-1}$. One set of mesocosms in each experiment did not have pumps (see below). The translucent lids were left on the mesocosms throughout the experiments in order to reduce light intensity and minimize evaporation. Light intensity measured $5 \mathrm{~cm}$ below the water surface in the mesocosms with lids in place ranged from 140 to $210 \mu \mathrm{mol}$ quanta $\mathrm{m}^{-2} \mathrm{~s}^{-1}$.

Expt 1. The first experiment was performed from 26 May to 4 June 2000. The goal of this experiment was to test conditions that we have previously used at a different study site to stimulate net population growth of Aureococcus anophagefferens in the experimental mesocosms and at the same time test whether the presence of relatively high abundances of Mercenaria mercenaria could prevent dominance by $A$. anophagefferens.

All mesocosms in this experiment were enriched daily with nitrogen as urea $(2.5 \mu \mathrm{M}$ nitrogen per day) and phosphorus as phosphate $\left(\mathrm{NaH}_{2} \mathrm{PO}_{4} ; 0.16 \mu \mathrm{M} \mathrm{d}^{-1}\right)$ to stimulate phytoplankton growth (N:P in approximate Redfield ratio). Overall, 3 treatments were performed with 6 replicate mesocosms in each treatment for a total of 18 mesocosms. However, 1 mesocosm from each of 2 treatments (Nutrients and Nutrients + Pump) were sacrificed on Days 3, 5 and 7 for use in another set of experiments not reported here (Caron et al. in press).

Nutrients: These mesocosms contained unfiltered seawater from Cedar Creek and an 'inoculum' of approximately 2.51 from Great South Bay, NY, to raise the concentration of Aureococcus anophagefferens to $1.3 \times 10^{4}$ cells $\mathrm{ml}^{-1}$ in each mesocosm. These mesocosms had no submersible pumps, but they were mixed manually with a plastic paddle twice daily (morning prior to sampling and late afternoon).

Nutrients + Pump: Our previous studies (Schaffner 1999) indicated that the presence of submersible aquarium pumps stimulated net growth of Aureococcus anophagefferens. These mesocosms contained Cedar Creek water and Great South Bay inoculum and a single submersible aquarium pump.

Clams + Nutrients + Pump: Mesocosms in this treatment contained the same setup as in 'Nutrients + Pump' above, as well as 19 Mercenaria mercenaria (average shell length $\pm \mathrm{SD}=40 \pm 3 \mathrm{~mm}$ ). This number of clams was equivalent to a density of approximately 67 clams $\mathrm{m}^{-2}$ of bottom. The clams were placed into round plastic containers (25 l capacity) with diameters slightly less than the diameter of the mesocosms. The clams used in the mesocosm studies were obtained from Blue Points Company, Bayville, NY. They were maintained at Blue Points Hatchery in running seawater at ambient temperature for $1 \mathrm{wk}$ after collecting. They were then transferred to Cedar Creek and allowed to acclimate to ambient conditions for 3 to $4 \mathrm{~d}$. Visual checks were made to ensure that the clams had extended their siphons prior to use.

Temperature near the surface $(10 \mathrm{~cm})$ and at middepth in all mesocosms was recorded daily prior to water sampling. Temperature increased by approximately $5^{\circ} \mathrm{C}$ from the start to the end of the experiment $\left(16.0\right.$ to $\left.20.7^{\circ} \mathrm{C}\right)$. The water column of each mesocosm was mixed manually prior to sample collection (approximately 10:00 h local time). Seawater samples for counts of Aureococcus anophagefferens were preserved with $10 \%$ gluteraldehyde prepared with $0.22 \mu \mathrm{m}$ filtered natural seawater (Sherr \& Sherr 1993) for a final preservative concentration of $1 \%$. A. anophagefferens cells were enumerated using the monoclonal antibody colorimetric technique of Caron et al. (2003). Replicate 25 to $72 \mathrm{ml}$ samples were filtered onto Gelman GF/F glass fiber filters for the measurement of total chl a concentration using a Turner Designs fluorometer, Model TD-700 (Arar \& Collins 1992).

Water samples were collected initially, and every second day for counts of the dominant microplankton (ciliated protozoa, dinoflagellates, diatoms and sarcodine protozoa, mostly heliozoa), and preserved with acid Lugol's solution (Stoecker et al. 1994). Samples for protistan counts were often stored for several months before processing, which is sufficient time for loss of autofluorescence of phototrophic protists. Therefore, no attempt was made to differentiate between photosynthetic and heterotrophic dinoflagellates using sodium thiosulfate to clear the iodine solution (Sherr \& Sherr 1993). Counts were performed on settled samples using an inverted microscope (Utermöhl 1958).

Micrometazoa and mesozooplankton (adults, copepodites and nauplii of copepods, and planktonic larvae of benthic species) were sampled at the beginning and end of the experiment. Two additional mesocosms were filled at the time each experiment was started. These mesocosms were sacrificed at the beginning of the experiment to obtain sufficient water (20 l each) for the zooplankton counts. The same amount of water was collected from each mesocosm at the end of the experiments. Zooplankton was concentrated on $64 \mu \mathrm{m}$ Nitex ${ }^{\circledR}$ screening, washed from the screening and preserved with $4 \%$ formalin. Counts were performed using a dissecting microscope.

The clearance rates of the clams in each mesocosm of the Clams + Nutrients + Pump treatment were determined at the end of the experiment (Day 9). We also determined the clearance rates of the clams from this treatment when placed into seawater from the Nutri- 
ents + Pump treatment to examine the effect of high abundances of Aureococcus anophagefferens that had developed in the Nutrients + Pump treatment. The plastic containers containing the clams and $25 \mathrm{l}$ of seawater from the mesocosm were removed from the Clams + Nutrients + Pump treatment. The clams from each mesocosm were split randomly into 2 groups of 9 clams. One group remained in the seawater from the Clams + Nutrients + Pump treatment. The other 9 clams were placed in seawater from the Nutrients + Pump treatment. The seawater was sampled at the beginning and end of a $2 \mathrm{~h}$ period and processed to determine chl a concentration. Seawater in the containers was gently mixed once every $15 \mathrm{~min}$ for $1 \mathrm{~min}$ during the incubation. Changes in chl a concentration were used to calculate total clearance rates of clams for phytoplankton in each container. These experiments were conducted at ambient temperature in late afternoon and early evening to minimize changes due to phytoplankton growth. Total clearance rates in each mesocosm were calculated using the clearance rate formula of Coughlan (1969). Individual clearance rates for the clams were calculated by dividing total clearance rate for each container by the number of clams (9).

Expts 2 and 3. Two $8 \mathrm{~d}$ mesocosm experiments with the same overall format were carried out at the SCMELC facility in 2001 from 27 May to 4 June and from 8 June to 16 June, to examine changes in pelagic community structure (including abundance of Aureococcus anophagefferens) in response to the number of clams in each mesocosm. Mesocosms were filled with seawater from Cedar Creek as described above. An 'inoculum' of 151 of Great South Bay seawater was added to each mesocosm for Expt 2 to obtain a starting concentration of A. anophagefferens of approximately $1.2 \times 10^{4}$ cells ml $^{-1}$, while 71 were added to each mesocosm for Expt 3 to obtain a starting concentration of approximately $1.1 \times 10^{4}$ cells ml ${ }^{-1}$. All mesocosms in Expts 2 and 3 were enriched daily with nutrients as described in Expt 1. Mixing was accomplished in all treatments except one (Nutrients) of both experiments using submersible aquarium pumps, and Mercenaria mercenaria were obtained, acclimated and deployed in mesocosms in the same manner as for Expt 1. Average shell lengths $( \pm \mathrm{SD})$ for clams in Expts 2 and 3 were $44 \pm 6$ and $43 \pm 4 \mathrm{~mm}$.

Overall, 6 treatments were performed in the 2 experiments, each treatment in triplicate, for a total of 18 mesocosms:

(1) Nutrients: These mesocosms contained unfiltered seawater from Cedar Creek and an inoculum of seawater from Great South Bay. They had no submersible pumps but they were mixed manually twice daily.

(2) Nutrients + Pump: This treatment was similar to treatment (1), except that each mesocosm had a single submersible aquarium pump placed into it.
(3 to 6) Nutrients + Pump $+\mathbf{N}$ Clams: These mesocosms were treated similarly to Treatment (2), except that each received $\mathrm{N}=2,4,8$ or 16 Mercenaria mercenaria. This number of clams was equivalent to a density of approximately $7,14,28$ or 56 clams $\mathrm{m}^{-2}$ of bottom.

Temperature recording, water sampling, processing of plankton samples and clam clearance rate estimates followed procedures described for Expt 1. Temperature increased from 16.8 to $17.8^{\circ} \mathrm{C}$ during Expt 2 and from 20.8 to $24.2^{\circ} \mathrm{C}$ during Expt 3 .

\section{RESULTS}

\section{Mesocosm Expt 1}

Both nutrient-enriched treatments without clams (Nutrients and Nutrients + Pump) attained high concentrations of chl a over the course of this $9 \mathrm{~d}$ experiment relative to starting concentrations (Fig. 1a). Chl a decreased initially in all treatments through Day 2 but then increased steadily in the 2 treatments without Mercenaria mercenaria. Chl a in the Nutrients + Pump treatment attained chl a values averaging approx-

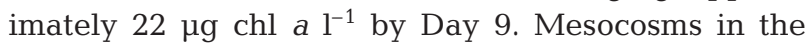
Nutrients treatment reached a maximum of approximately $17 \mu \mathrm{g} \mathrm{chl} \mathrm{a} \mathrm{l}^{-1}$ on Day 7 . In contrast, chl $a$ in the Clams + Nutrients + Pump treatment did not increase during the experiment, reaching approximately $2.5 \mu \mathrm{g}$ chl a $\mathrm{l}^{-1}$ by Day 2 and concentrations remained near that level until the end of the experiment. The time course of changes in chl a concentration over the duration of the experiment differed significantly from concentrations in the Nutrients and Nutrients+Pump treatments (modified ANCOVA $;$ p < 0.05). There were no significant differences between the Nutrients and Nutrients + Pump treatments.

High concentrations of Aureococcus anophagefferens developed in all nutrient-enriched mesocosms that did not have clams present (Fig. 1b). Abundances of the brown tide alga reached average maxima of approximately $3.0 \times 10^{5}$ cells ml ${ }^{-1}$ in both the Nutrients and Nutrients + Pump treatments, and no significant differences were observed between these 2 treatments $(p<0.05)$. Mesocosms with clams showed no increase in the abundance of $A$. anophagefferens for the duration of the experiment. Final abundances of the alga in this treatment were approximately 2 orders of magnitude less than in the Nutrients and Nutrients + Pump treatments $(<5 \times$ $10^{3}$ cells ml ${ }^{-1}$ on Day 8; Fig. $1 \mathrm{~b}$ ), and were significantly different from those treatments from Day 1 through the end of the experiment $(\mathrm{p}<0.05)$.

The presence of clams also had a dramatic effect on the relative abundance of Aureococcus anophagefferens in the phytoplankton assemblages that developed 

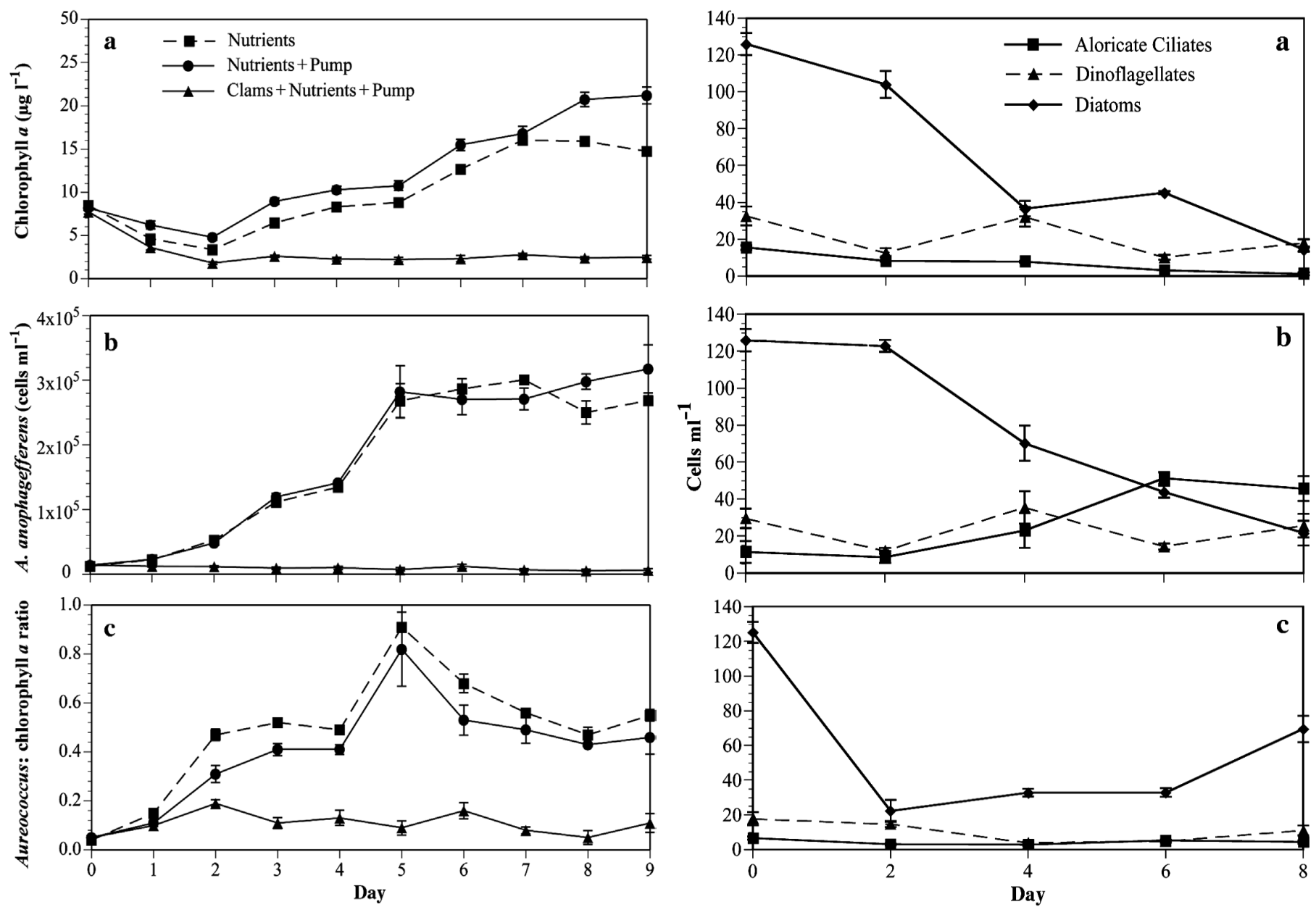

Fig. 1. (a) Changes in chlorophyll a concentration, (b) abundance of Aureococcus anophagefferens and (c) Aureococcus: chlorophyll ratio in a $9 \mathrm{~d}$ mesocosm experiment (Expt 1) designed to examine the effect of nutrient enrichment (with and without mechanical stirring) and the presence of northern quahog Mercenaria mercenaria. Values are means $( \pm \mathrm{SE})$

during the experiment (Fig. 1c). The ratio of the biomass of A. anophagefferens to total phytoplankton biomass was estimated by converting $A$. anophagefferens cell abundances to chl a concentrations using a value of $0.033 \mathrm{pg} \mathrm{chl} \mathrm{a} \mathrm{cell}{ }^{-1}$ (Gobler 1995). The Aureococcus: chl a ratio for the Nutrients treatment averaged $\sim 63 \%$ from Day 5 through the end of the experiment. The Nutrients + Pump treatment averaged $\sim 55 \%$ for the same period (Fig. 1c). In contrast, the Aureococcus: chl a ratio in the Clams + Nutrients + Pump treatment averaged only $12 \%$ for this period.

Microplankton assemblages (20 to $200 \mu \mathrm{m}$ protists) were numerically dominated by aloricate ciliates, dinoflagellates and diatoms (Fig. 2). Diatoms showed the most dramatic changes in abundance, dropping precipitously during the first several days of the experiment in all treatments. Diatoms then increased slowly

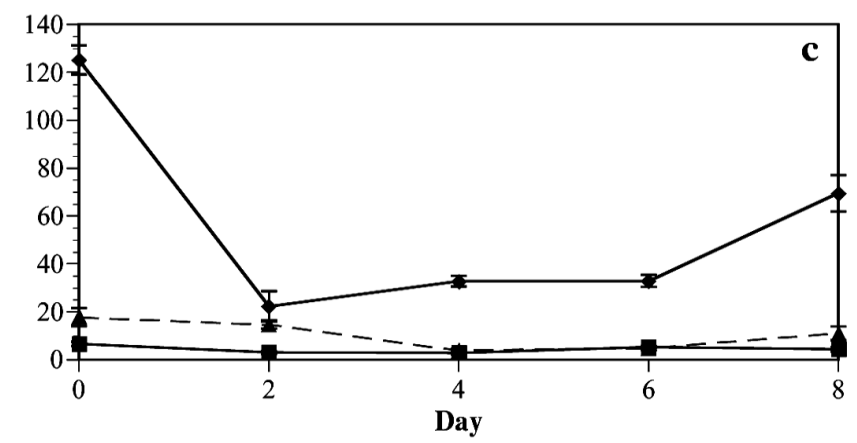

Fig. 2. Abundances of the numerically dominant taxa of microplankton (aloricate ciliates, dinoflagellates, diatoms) in 3 treatments of Expt 1: (a) Nutrients, (b) Nutrients + Pump,

(c) Clams + Nutrients + Pump. Values are means $( \pm \mathrm{SE})$

for the remainder of the experiment in the Clams+ Nutrients + Pump treatment (Fig. 2c), but not in the Nutrients or Nutrients + Pump treatments (Fig. 2a,b) The increase in the Clams + Nutrients + Pump treatment was due predominantly to pennate diatoms that grew on the sides of the mesocosms in this treatment. Ciliate and dinoflagellate assemblages decreased to relatively low abundances in the presence of clams and remained low throughout the experiment (Fig. 2c). The abundance of ciliates increased in the Nutrients + Pump treatment towards the end of the experiment, but otherwise ciliate and dinoflagellate assemblages remained fairly stable in the Nutrients and Nutrients + Pump treatments (Fig. 2a,b).

Micrometazoa and mesozooplankton assemblages exhibited a more pronounced response to the presence of clams than did protistan assemblages (Fig. 3a). Large populations of copepodite and adult stages of calanoid copepods, and larvae of benthic invertebrates were pre- 

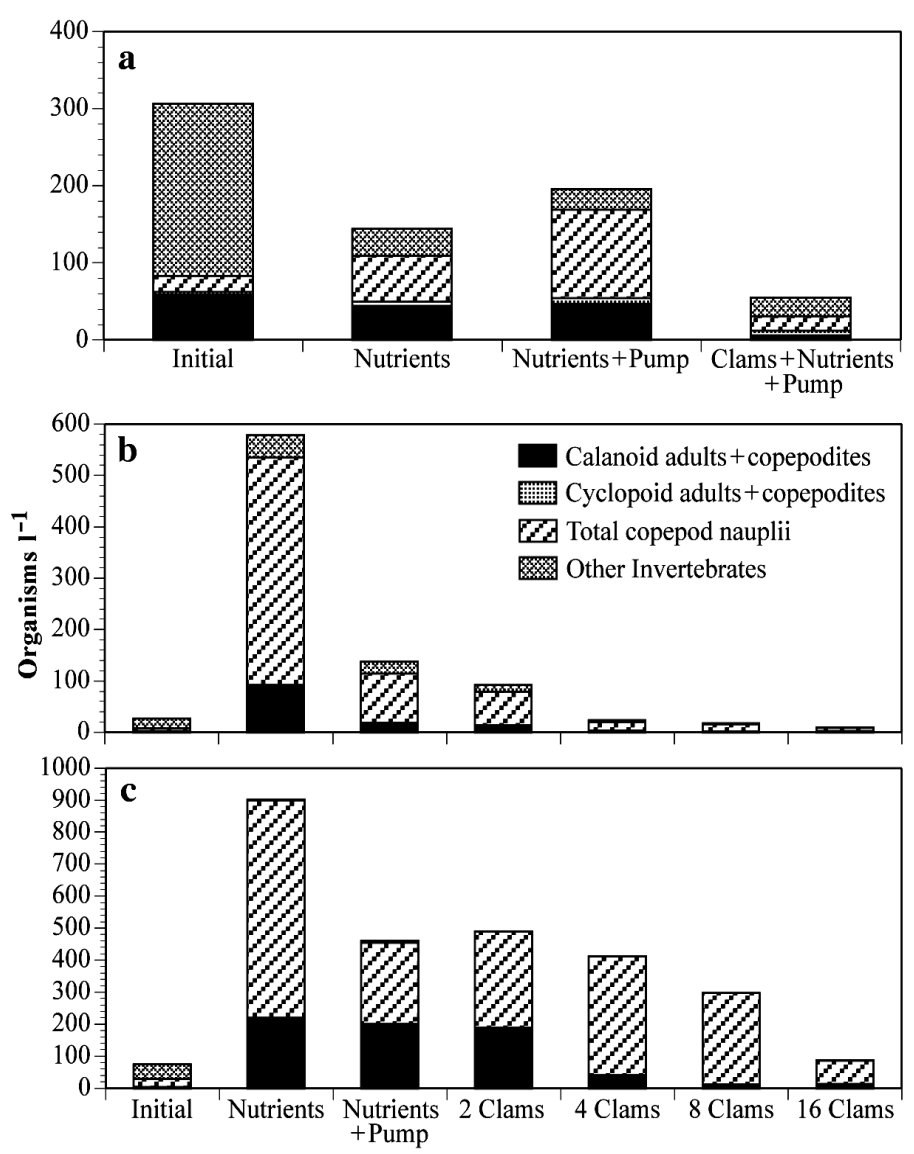

Fig. 3. Mean abundances of the numerically dominant taxa of micrometazoa and mesozooplankton $(>64 \mu \mathrm{m})$ in mesocosms during (a) Expt 1, (b) Expt 2 and (c) Expt 3

sent at the beginning of this experiment. The latter taxa decreased in all treatments over the course of the experiment due to settlement and/or death. However, abundances of copepodites and calanoid adults were substantially reduced in the Clams + Nutrients + Pump treatment relative to initial values or abundances in the Nutrients and Nutrients + Pump treatments at the end of the experiment. Likewise, abundances of copepod nauplii in the treatment with Mercenaria mercenaria remained similar to initial values while nauplii increased 3 to $5 \times$ in the Nutrients and Nutrients + Pump treatments.

Clearance rates of Mercenaria mercenaria in the 6 replicates of the Clams + Nutrients + Pump treatment were $1.2 \pm 0.4 \mathrm{l} \mathrm{clam}^{-1} \mathrm{~h}^{-1}$ (average $\pm \mathrm{SE}$ ). This clearance rate was sufficient to prevent an increase of phytoplankton biomass and a shift in the species composition of the phytoplankton to dominance by Aureococcus anophagefferens. Clearance rate was depressed by $17 \times$ to $0.07 \pm 0.071 \mathrm{clam}^{-1} \mathrm{~h}^{-1}$ when clams from this treatment were placed into seawater from the Nutrients + Pump treatment (Fig. 4). The abundance of Aureococcus anophagefferens in these latter mesocosms ranged from approximately 2.5 to $3.8 \times 10^{5}$ cells $\mathrm{ml}^{-1}$. Based on clearance rate results, filtration by 19 clams in the mesocosms of the Clams + Nutrients + Pump treatment would have constituted a turnover rate for the water of $0.51 \mathrm{~d}$ compared to $8.8 \mathrm{~d}$ in the seawater from the Nutrients + Pump mesocosms.

\section{Mesocosm Expt 2}

Chl a concentrations in Expt. 2 increased in response to nutrient enrichment in 4 of the 6 treatments (Fig. 5a). Phytoplankton biomass in the Nutrients treatment of Expt 2 reached a maximum similar to this treatment in

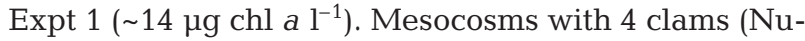
trients + Pump +4 clams treatment) attained a similar

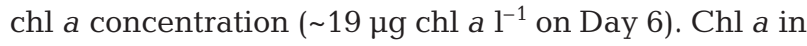
the Nutrients + Pump and Nutrients + Pump +2 clams treatments also increased steadily for much of the $8 \mathrm{~d}$ experiment but these treatments attained concentrations considerably higher than chl a maxima observed in Expt 1 (average of $\sim 39$ and $42 \mu \mathrm{g} \mathrm{chl} \mathrm{a} \mathrm{^{-1 }}$, respectively).

In contrast to the results in these 4 sets of mesocosms, treatments with 8 or 16 Mercenaria mercenaria (Nutrients + Pump +8 clams and Nutrients + Pump +16 clams) showed decreases in chl a concentration over the length of the experiment (Fig. 5a). Both treatments had stable average chl a values from Day 4 through Day 8 of

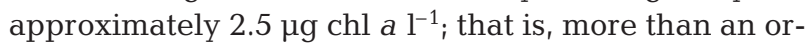
der of magnitude lower than maxima observed in the Nutrients + Pump and Nutrients + Pump + 2 clams treatments. The Nutrients + Pump +8 clams and Nutrients +

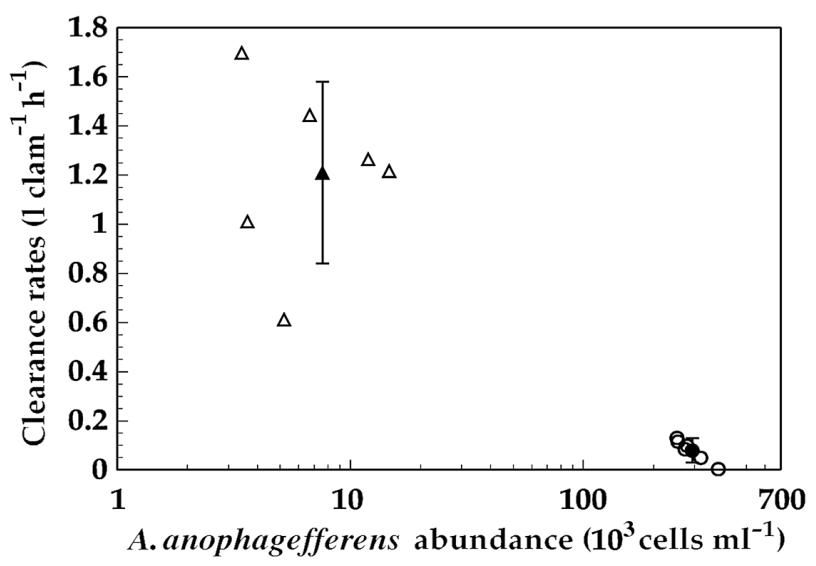

Fig. 4. Mercenaria mercenaria. Clearance rates from 6 replicate mesocosms of the Clams + Nutrients + Pump treatment of Expt 1. Clams from each tank were divided into 2 groups at the end of the experiment. One set of clams remained in water from the Clams + Nutrients + Pump mesocosms $\left(\Delta_{i} \boldsymbol{\Delta}\right.$ is the mean of the 6 measurements). The second set of clams was placed in water from the Nutrients + Pump treatment $(0 ; \bullet$ is the mean of the 6 measurements $)$ 
Pump +16 clams treatments were significantly different from all other treatments after Day 2 (modified ANCOVA; $\mathrm{p}<0.05)$.

Significant increases in Aureococcus anophagefferens abundances occurred in only 2 of the treatments in Expt 2 (Nutrients + Pump and Nutrients + Pump + 2 clams; Fig. 5b). The time courses of $A$. anophagefferens abundances in these 2 treatments were significantly different from all other treatments $(p<0.05)$ but not from each other throughout the experiment. The Nutrients + Pump treatment reached a maximum of $4.2 \times 10^{5}$ A. anophagefferens cells $\mathrm{ml}^{-1}$ on Day 6, while the Nutrients + Pump +2 clams treatment attained an
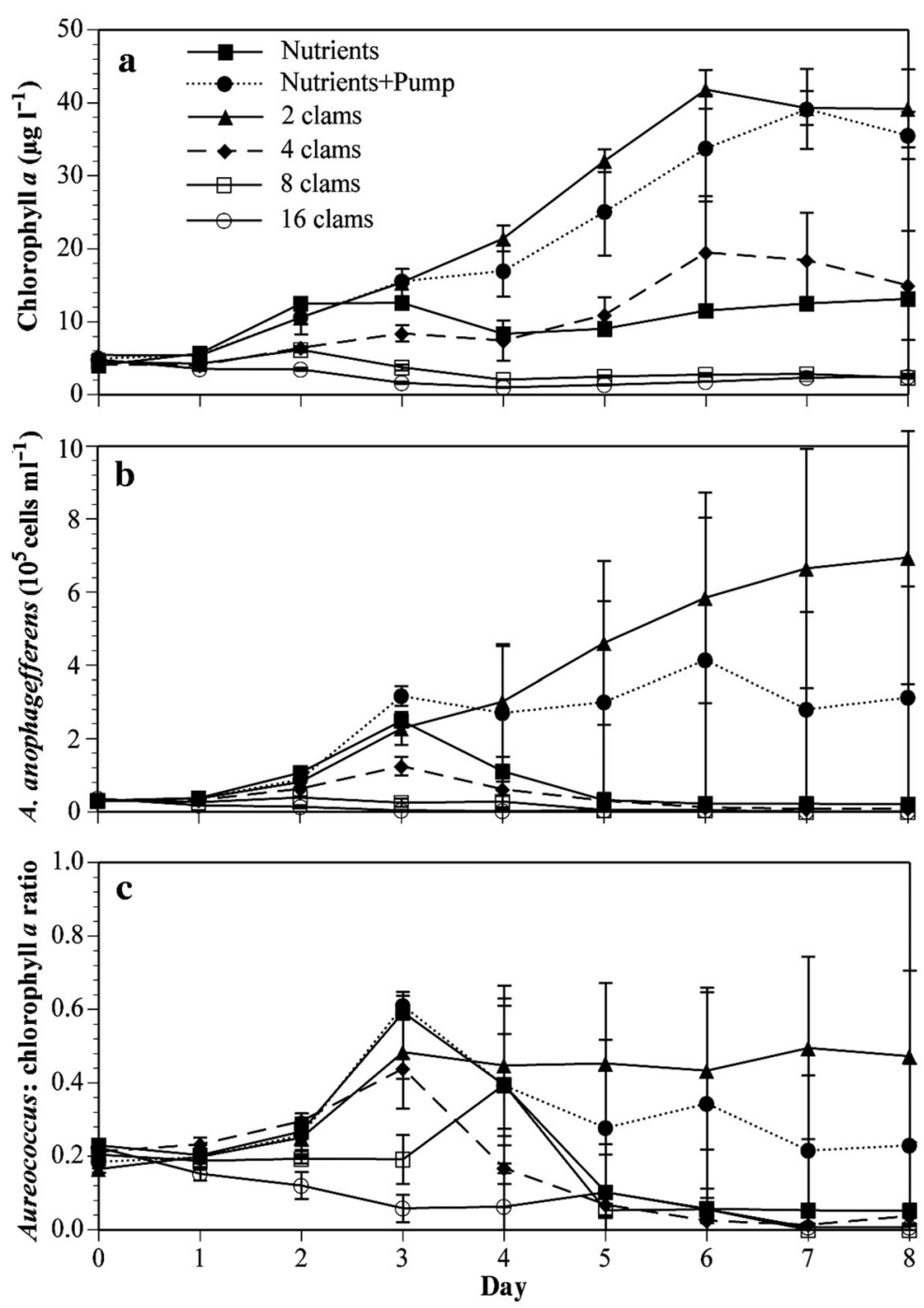

Fig. 5. Expt 2. (a) Changes in chlorophyll a concentration, (b) abundance of Aureococcus anophagefferens and (c) Aureococcus:chl a ratio (mean $\pm \mathrm{SE}$ ). All mesocosms were enriched with nitrogen and phosphorus. Mesocosms in the Nutrients + Pump treatment and the 4 treatments with clams were stirred using submersible pumps average maximum of $6.9 \times 10^{5}$ cells $\mathrm{ml}^{-1}$ on Day 8 . However, we observed extreme variability among the mesocosms within these 2 treatments resulting in large error bars. A. anophagefferens in all of the mesocosms of the Nutrients + Pump treatment increased rapidly at the beginning of the experiment to approximately $3 \times 10^{5}$ cells $\mathrm{ml}^{-1}$ by Day 3 , but then abundance in 2 of 3 mesocosms decreased to $\sim 10^{4}$ cells $\mathrm{ml}^{-1}$ by the end of the experiment. The remaining mesocosm maintained very high abundances of the brown tide alga until Day $8\left(>9 \times 10^{5}\right.$ cells ml $\left.{ }^{-1}\right)$. Similarly, A. anophagefferens in all of the mesocosms of the Nutrients + Pump +2 clams treatment increased rapidly to 1.5 to $3.1 \times 10^{5}$ cells $\mathrm{ml}^{-1}$ by Day 3 , but then abundance in 2 of these mesocosms continued to increase (up to abundances $>1 \times 10^{6}$ cells ml $^{-1}$ ), while abundance in the third mesocosm decreased to $\sim 10^{4}$ cells $\mathrm{ml}^{-1}$. Total phytoplankton biomass in this latter mesocosm remained high, but $A$. anophagefferens was replaced by diatoms as the dominant phytoplankton taxon.

Aureococcus anophagefferens exhibited minor increases in abundance on Day 3 in the Nutrients $\left(2.5 \times 10^{5}\right.$ cells $\left.\mathrm{ml}^{-1}\right)$ and Nutrients + Pump +4 clams treatments $\left(1.2 \times 10^{5}\right.$ cells $\left.\mathrm{ml}^{-1}\right)$, but abundances returned to low values by Day 5 . Treatments with 8 or 16 clams maintained very low abundances of the brown tide alga throughout the $8 \mathrm{~d}$ experiment (near or below the limit of

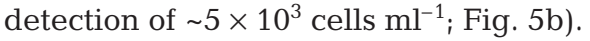

The Aureococcus:chl a ratio for all treatments in Expt 2 was $\sim 20 \%$ at the beginning of the experiment (Fig. 5c). This ratio increased to 40 to $60 \%$ by Day 4 for all treatments except the treatments with 8 or 16 clams. The ratio remained at $\sim 50 \%$ in the Nutrients + Pump +2 clams treatment for the remainder of the experiment and $20 \%$ in the Nutrients + Pump treatment. However, the ratio was variable among mesocosms in these 2 treatments due to variability in the abundance of Aureococcus anophagefferens as noted above. Ratios in the other treatments decreased after Days 3 to 4 to values $<10 \%$ by the end of the experiment.

Abundances of micrometazoa and mesozooplankton increased dramatically during the experiment only in the Nutrients treatment (Fig. 3b). Large increases were observed in the abundances of copepod nauplii as well as copepodite and adult stages of calanoid copepods. Zooplankton increased $\sim 30 \times$ in the Nutrients treatment by the end of the experiment (500 organisms $1^{-1}$ by Day 8 ). This value was $4 \times$ the abundance of zooplankton obtained in the comparable treatment of Expt 1 (Fig. 3a,b). 
Micrometazoa and mesozooplankton (mostly copepod nauplii) also increased in the Nutrients + Pump treatment, but the increase was modest relative to the Nutrients treatment. Zooplankton abundance in the Nutrients + Pump treatments of Expts 1 and 2 differed by less than a factor of 2 by the end of the 2 experiments. The presence of 2 clams had little effect on zooplankton relative to the treatment with pumps but without clams (compare Nutrients + Pump and Nutrients + Pump +2 clams treatments in Fig. 3b). The presence of 4,8 or 16 clams resulted in zooplankton assemblages that remained virtually unchanged from initial abundances during the $8 \mathrm{~d}$ experiment except for slight shifts in relative abundances of some taxa (increases in nauplii and the loss of planktonic larvae of benthic invertebrates).

Changes in the abundances of protistan microplankton in the treatments without Mercenaria mercenaria reflected changes in the micrometazoa/mesozooplank- ton assemblages (compare Fig. 3b with Fig. 6a,b). Very high abundances of larger zooplankton in the Nutrients treatment were reflected in relatively low abundances of protistan microplankton taxa (Fig. 6a), while much lower abundances of larger zooplankton in the Nutrients + Pump treatment were reflected in higher abundances of most protistan microplankton taxa (Fig. 6b). In addition, dramatic shifts in the absolute and relative abundances of aloricate ciliates and diatoms were observed in the Nutrients + Pump treatment that were not observed in the Nutrients treatment.

Protistan microplankton abundances in the treatments with Mercenaria mercenaria in Expt 2 were generally similar for the mesocosms with 2 or 4 clams on the one hand, and the mesocosms with 8 or 16 clams on the other hand. The Nutrients + Pump +2 clams and Nutrients + Pump +4 clams treatments developed high abundances of aloricate ciliates and diatoms, and these assemblages exhibited patterns in their abundances that were similar to the pattern observed for the Nutrients + Pump treatment (Fig. 6b,c,d). Protistan microplankton abundances in the Nutrients + Pump +8 clams and Nutrients + Pump + 16 clams treatments were considerably lower than in the mesocosms with 2 or 4 clams (note different ranges for diatoms) and generally showed modest changes in abundance throughout the experiment relative to the other mesocosms (Fig. 6e,f).

Total clearance of phytoplankton biomass by clams within the mesocosms varied directly with the abundance of bivalves in the treatments (Fig. 7a). Clearance rates in treatments with 8 or 16 clams were significantly higher than rates observed in the Nutrients + Pump or Nutrients + Pump +2 clams treatments. These clearance rates corresponded to average turnover times for seawater in the mesocosms of $1.1 \mathrm{~d}$ (Nutrients + Pump + 8 clams) and $0.85 \mathrm{~d}$ (Nutrients + Pump +16 clams). In contrast, average turnover times for the other treatments were $2.4 \mathrm{~d}$ (Nutrients + Pump +4 clams) and $11 \mathrm{~d}$ (Nutrients + Pump +2 clams). Net changes in chl a concentrations during the same $2 \mathrm{~h}$ period were equivalent to a turnover time of $4.5 \mathrm{~d}$ for the phytoplankton assemblages in the Nutrients + Pump treatment due to pelagic microbial herbivory. It is noteworthy, however, that zooplankton abundances in this latter
Fig. 6. Expt 2. Abundances (mean $\pm \mathrm{SE}$ ) of the dominant taxa of protistan microplankton (aloricate and loricate ciliates, dinoflagellates, diatoms) in 6 treatments: (a) Nutrients, (b) Nutrients + Pump, (c) Nutrients + Pump +2 clams, (d) Nutrients + Pump + 4 clams, (e) Nutrients + Pump + 8 clams, (f) Nutrients + Pump +16 clams 
treatment were roughly 1 order of magnitude greater than abundances in the treatments with 8 or 16 clams.

Individual clearance rates for Mercenaria mercenaria in the Nutrients + Pump +16 clams treatment of Expt 2 were calculated assuming that the activity of the clams dominated herbivory in that treatment. The rate for clams in that experiment averaged $0.86 \mathrm{l} \mathrm{clam}^{-1} \mathrm{~h}^{-1}$.

\section{Mesocosm Expt 3}

Temporal patterns of chl a concentration, abundances of Aureococcus anophagefferens and the Aureococcus:chl a ratios during Expt 3 were similar to the general patterns observed in Expt 2 (Fig. 8). Substantial increases in chl a concentration occurred in the Nutrients, Nutrients + Pump and Nutrients + Pump +2 clams treatments (Fig. 8a). Chl a attained values $\geq 20 \mu \mathrm{g}^{-1}$ in these treatments by Day 4, although it subsequently decreased in the Nutrients treatment. This pattern was similar to the overall pattern observed in Expt 2, where the Nutrients treatment increased initially but then did not keep pace with the buildup of phytoplankton biomass in the Nutrients + Pump and Nutrients + Pump +2 clams treatments

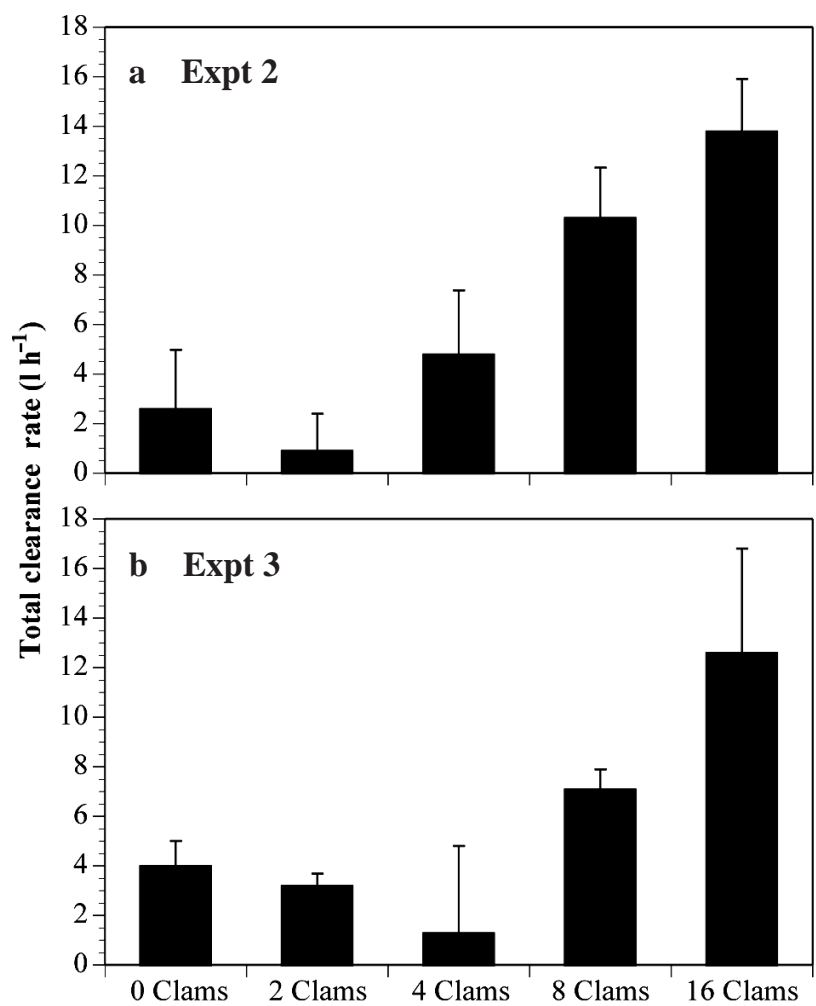

Fig. 7. Total clearance rates (removal of chlorophyll) measured in the 5 treatments of (a) Expt 2 and (b) Expt $3( \pm \mathrm{SE}$ based on measurements in 3 triplicate mesocosms)
(Fig. 5a). The Nutrients + Pump +8 clams and Nutrients + Pump +16 clams treatments maintained low concentrations of chl a (generally $<5 \mu \mathrm{g} \mathrm{l}^{-1}$ ) and were significantly different from biomass in all other treatments after Day $2(\mathrm{p}<0.05)$. Chl a in the Nutrients + Pump +4 clams treatment remained relatively stable for most of the 8 -d period at $\approx 10 \mu \mathrm{g}^{-1}$. Phytoplankton biomass in that treatment was significantly greater than in the Nutrients + Pump +8 clams and Nutrients + Pump +16 clams treatments, but remained significantly lower than in the Nutrients + Pump and Nutrients + Pump +2 clams treatments after Day $2(p<0.05)$.

Net population growth of Aureococcus anophagefferens occurred in all mesocosms except the Nutrients + Pump + 8 clams and Nutrients + Pump +16 clams treatments (Fig. 8b). A. anophagefferens abundances in these 2 treatments were significantly less than in all other treatments after Day 1 ( $\mathrm{p}<0.05)$. These values represent abundances of $A$. anophagefferens more than 2 orders of magnitude less than maxima attained in the Nutrients, Nutrients + Pump and Nutrients + Pump +2 clams treatments. Abundances of the alga increased dramatically during the first $6 \mathrm{~d}$ of the experiment in the Nutrients, Nutrients + Pump and Nutrients + Pump +2 clams treatments and then decreased during the last $2 \mathrm{~d}$. There were no significant differences among the patterns of $A$. anophagefferens abundances in these latter 3 treatments over the course of the experiment. Maximal average abundances attained in these treatments were 5.2, 6.0 and $5.9 \times 10^{5}$ cells $\mathrm{ml}^{-1}$, respectively. A. anophagefferens increased more slowly but steadily in the Nutrients + Pump +4 clams treatment and attained an average maximum of $1.8 \times 10^{5}$ cells $\mathrm{ml}^{-1}$ by Day 8 . A. anophagefferens abundance in that treatment was significantly greater than in the Nutrients + Pump +8 clams and Nutrients + Pump +16 clams treatments after Day 1 but remained significantly lower than in the Nutrients + Pump and Nutrients + Pump +2 clams treatments $(p<0.05)$. Within-treatment variability observed during Expt 3 was much less than observed in Expt 2.

Dominance of the phytoplankton assemblage by the brown tide alga differed markedly among the treatments of Expt 3 as indicated by differences in the Aureococcus:chl a ratio (Fig. 8c). The Nutrients treatment was very strongly dominated by Aureococcus anophagefferens by Day 6. Maxima in the ratio were also observed on Day 6 for Nutrients + Pump and Nutrients + Pump +2 clams treatments. The Aureococcus:chl a ratio for the Nutrients + Pump +4 clams treatment increased slowly and steadily throughout the experiment, mirroring the increase in the absolute abundance of $A$. anophagefferens in this treatment (Fig. 8b). In contrast to these treatments, mesocosms with 8 or 16 Mercenaria mercenaria (Nutrients + 

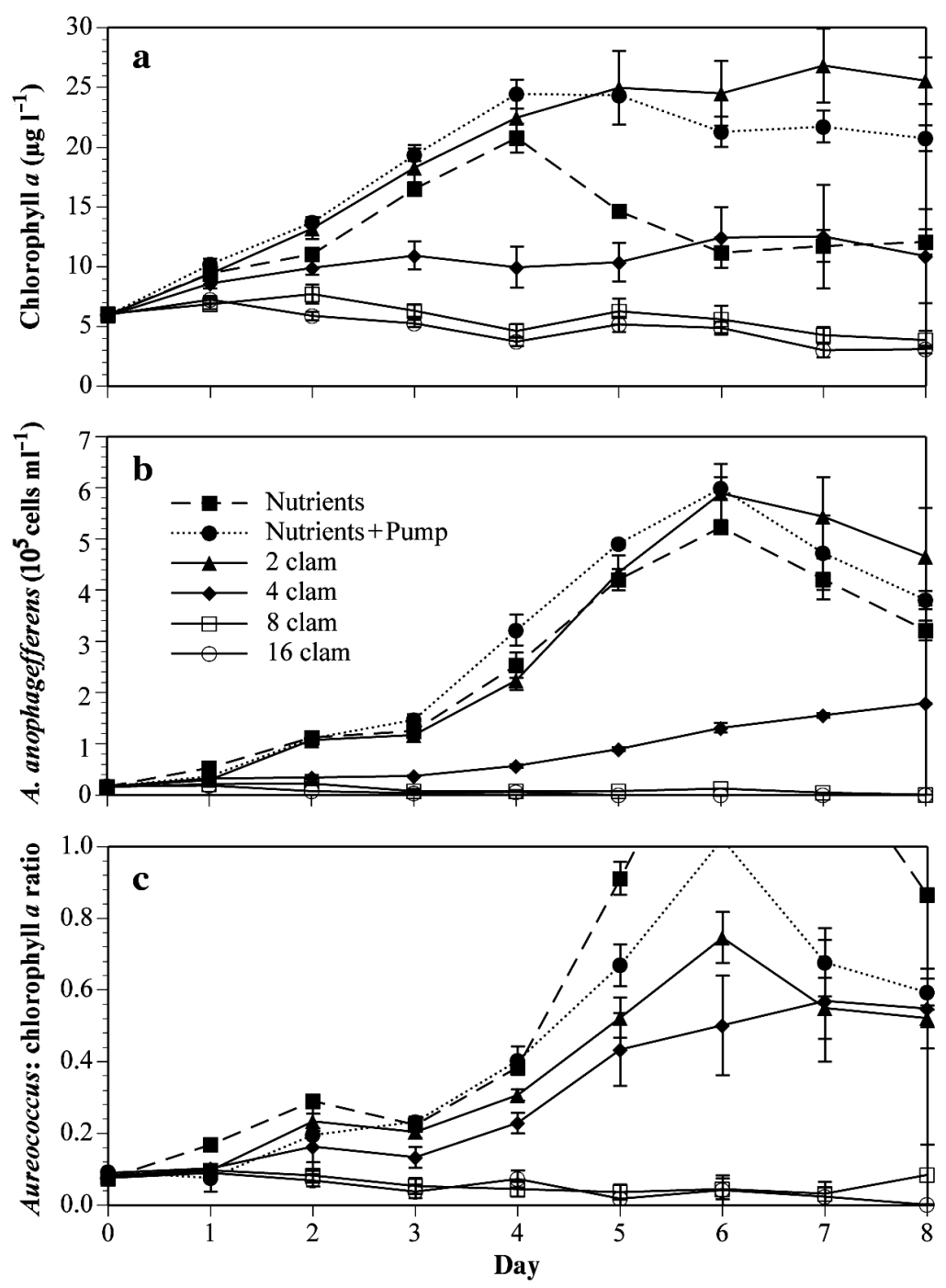

Fig. 8. Expt 3. (a) Changes in chlorophyll a concentration, (b) abundance of Aureococcus anophagefferens and (c) Aureococcus:chl a ratio (mean $\pm \mathrm{SE}$ ). All mesocosms were enriched with nitrogen and phosphorus. Mesocosms in the Nutrients + Pump treatment and the 4 treatments with clams were stirred using submersible pumps

Pump + 8 clams and Nutrients + Pump +16 clams) maintained Aureococcus:chl a ratios near zero (open symbols in Fig. 8c).

The highest Aureococcus:chl a ratios for 2 of the treatments in Expt 3 exceeded the theoretical maximum of 1.0 (i.e. all chl a attributable to Aureococcus anophagefferens). This result indicates that the value of $0.033 \mathrm{pg}$ cell $^{-1}$ employed to estimate chl a of the brown tide population was not accurate for this experiment. Nevertheless, the relative differences in this ratio indicated much greater dominance of the brown tide alga in mesocosms without clams or with low abundances of clams.

Larger zooplankton were considerably more abundant in Expt 3 relative to abundances in Expt 2, but temporal patterns of larger zooplankton and protistan microplankton were similar in many respects between the 2 experiments (compare Fig. 3b,c and Figs. 6 and 9). Larger zooplankton abundance in the Nutrients treatment was $10 \times$ greater than initial abundances and approximately $2 \times$ greater than final abundances in any of the other treatments (Fig. 3c). Increases in stages of calanoid copepods constituted the majority of the increase. Changes in the abundances of larger zooplankton in the Nutrients + Pump and Nutrients + Pump + 2 clams treatments were similar to each other. These latter treatments were approximately $5 \times$ greater than initial abundances but only one half the abundance observed in the Nutrients treatment after $8 \mathrm{~d}$. Average abundance in the Nutrients + Pump +16 clams treatment remained low and did not change appreciably from initial abundance except for a shift in dominant taxa (i.e. the loss of planktonic larvae of benthic invertebrates and a slight increase in nauplii).

Changes in larger zooplankton in the Nutrients + Pump +4 clams and Nutrients + Pump +8 clams treatments of Expt 3 were somewhat different than changes observed in Expt 2 (Fig. 3b,c). Abundance in Expt 3 increased in the Nutrients + Pump +4 clams treatment to a similar degree as the Nutrients + Pump and Nutrients + Pump +2 clams treatments of this experiment (approximately $5 \times$ greater than initial abundance), and only slightly less in the Nutrients + Pump +8 clams treatment.

Protistan microplankton abundances were less variable in Expt 3 than in Expt 2, presumably reflecting the higher abundances of larger zooplankton species in Expt 3 (Fig. 9). Diatoms and dinoflagellates were the most abundant taxa in all treatments, but these species were maintained at relatively low abundances in treatments with 4,8 or 16 Mercenaria mercenaria (Fig. 9d,e,f) compared to mesocosms with 2 clams or without clams (Fig. 9a,b,c).

The pattern of total clearance rates of clams among the treatments in Expt 3 mirrored the general pattern observed in Expt 2 (Fig. 7). The Nutrients + Pump +8 clams and Nutrients + Pump +16 clams treatments maintained the highest grazing impact on phytoplankton assemblages. Average total clearance rate in the Nutrients + Pump +16 clams treatment in Expt 3 was 

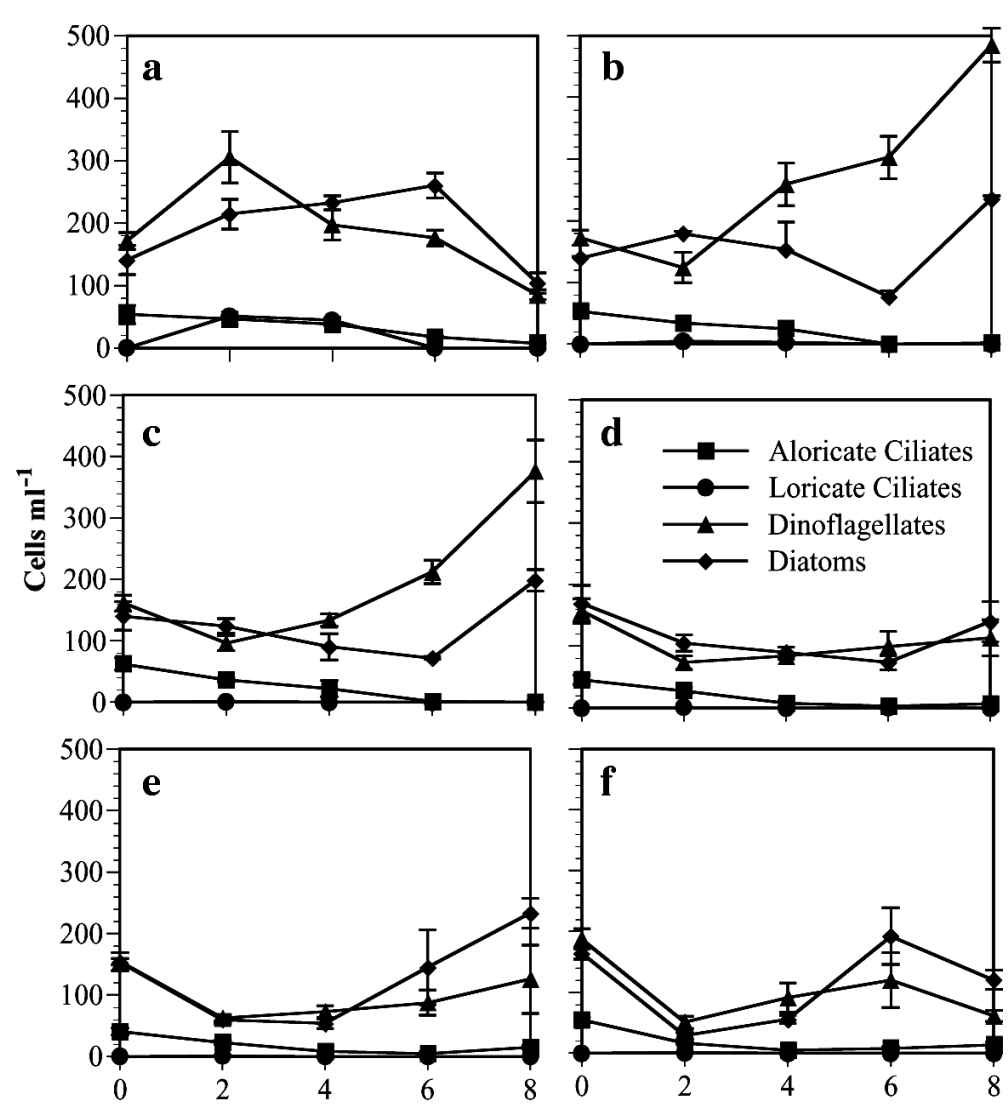

Fig. 9. Expt 3. Abundances (mean $\pm \mathrm{SE}$ ) of the dominant taxa of protistan microplankton (aloricate and loricate ciliates, dinoflagellates, diatoms) in 6 treatments: (a) Nutrients, (b) Nutrients + Pump, (c) Nutrients + Pump + 2 clams, (d) Nutrients + Pump +4 clams,

(e) Nutrients +Pump +8 clams, (f) Nutrients +Pump +16 clams

similar to the rate in the same treatment of Expt 2 (12.6 and $13.8 \mathrm{l} \mathrm{h}^{-1}$, respectively), while the rate in the Nutrients + Pump + 8 clams treatment was somewhat lower in Expt 3 ( 7.1 vs $10.3 \mathrm{l} \mathrm{h}^{-1}$ ). These clearance rates constituted average turnover times for seawater in the mesocosms of $1.6 \mathrm{~d}$ (Nutrients + Pump +8 clams) and 0.93 d (Nutrients + Pump +16 clams) for Expt 3 .

Individual clearance rates for Mercenaria mercenaria in the Nutrients + Pump +16 clams treatment of Expt 3 averaged $0.79 \mathrm{l} \mathrm{clam}^{-1} \mathrm{~h}^{-1}$, assuming that the activity of the clams dominated herbivory in this treatment. Pelagic microbial herbivory appeared to constitute a grazing impact that was similar to 2 or 4 clams (note '0 clams' treatment in Fig. 7b).

\section{DISCUSSION}

\section{Experimentally induced brown tides}

The development and manipulation of an experimental system for examining the environmental factors contributing to outbreaks of brown tides caused by Aureococcus anophagefferens has been a primary goal in our investigations of these phenomena. Our mesocosm approach was designed to provide an experimental framework within which to test specific factors that have been implicated in stimulating brown tides.

We have speculated previously why the use of submersible pumps resulted in dominance of Aureococcus anophagefferens in our contained phytoplankton communities (Schaffner 1999). Regardless of their specific action, the pumps somehow altered pelagic community structure in a way that favored net growth of $A$. anophagefferens in our previous experiments. Therefore, we used this approach in our present study to create conditions that we believed would be conducive to stimulating $A$. anophagefferens growth in our mesocosms in order to provide a means of examining the interaction between the brown tide alga and the suspension-feeding bivalve Mercenaria mercenaria.

The results of Expt 1 confirmed our previous work at a different study site in that the brown tide alga reached very high absolute and relative abundances in nutrient enriched mesocosms with mechanical stirring (Fig. 1b,c). In addition, high absolute and relative abundances of Aureococcus anophagefferens were observed in the nutrient enriched mesocosms without pumps in Expt 1. This latter result was unique from our previous studies because A. anophagefferens did not bloom in mesocosms receiving nutrients without mechanical stirring in those studies. It indicated that pelagic food web structure in the mesocosms during 2000 was conducive to net growth of the brown tide alga even without pumps present. Nutrient enrichment alone was sufficient to induce a substantial brown tide (A. anophagefferens abundances $>3 \times 10^{5}$ cells $\mathrm{ml}^{-1}$; Fig. 1b) and a phytoplankton assemblage in which the brown tide alga constituted a major fraction of the total chl a (Fig. 1c). This result indicated that our mesocosms were capable of supporting blooms of $A$. anophagefferens in the absence of the submersible aquarium pumps (which obviously represents an artificial means of inducing brown tides).

The net growth rate of phytoplankton in the nutrient enriched mesocosms without clams in Expt 1 (Nutrients and Nutrients + Pump treatments) was approximately $0.3 \mathrm{~d}^{-1}$ based on the rate of increase of chl $a$ in these treatments from Day 2 through Day 8. In contrast, net growth rate for the brown tide alga in these treatments was $0.6 \mathrm{~d}^{-1}$ from Day 1 through Day 5 (compare slopes in Fig. 1a,b). These differences in net growth rate between the brown tide alga and other 
phytoplankton species resulted in a rapid shift in the relative abundance of Aureococcus anophagefferens in all mesocosms without clams by Day 5 (Fig. 1c). Maximal relative abundance of $A$. anophagefferens occurred on Day 5 in the mesocosms without clams and decreased somewhat throughout the rest of the experiment. Interestingly, total phytoplankton biomass continued to increase after Day 5 in these mesocosms while $A$. anophagefferens abundance remained stable after Day 5. Clearly, phytoplankton growth was not limited by nutrient availability because nutrients were added daily to these mesocosms and phytoplankton other than $A$. anophagefferens continued to grow (until Day 7 in the Nutrients treatment and until Day 8 in the Nutrients + Pump treatment).

The absolute and relative abundances of Aureococcus anophagefferens also increased dramatically in the nutrient enriched treatments without clams in Expts 2 and 3 of the present study (Nutrients + Pump treatment in Figs. 5 and 8). Net population growth rate of $A$. anophagefferens was $0.9 \mathrm{~d}^{-1}$ in Expt 2, while the growth rate of the entire phytoplankton assemblage was $0.5 \mathrm{~d}^{-1}$. However, we observed large variability in the development of brown tides among the 3 mesocosms of this treatment in Expt 2. Growth of the alga was similar in all mesocosms through Day 3, but only 1 of the mesocosms developed very high abundances of $A$. anophagefferens (maximal abundance approximately $1.2 \times 10^{6}$ cells $\mathrm{ml}^{-1}$ ). This value is comparable to abundances of the alga in some of the most severe brown tides observed in nature (Bricelj \& Lonsdale 1997). Abundances in the other 2 mesocosms of this treatment peaked at lower values $\left(2.8 \times 10^{5}\right.$ and $3.7 \times 10^{5}$ cells $\mathrm{ml}^{-1}$ ). Variance in the concentration of total chl a was much less among these mesocosms (Fig. 5a), indicating that phytoplankton accumulated in all mesocosms even if $A$. anophagefferens did not.

The exact reason for this within-treatment variability in the abundance of Aureococcus anophagefferens in Expt 2 is unknown. Within-treatment variability in Expt 3 was much lower (Fig. 8b). The high variability observed in Expt 2 demonstrates the stochastic nature of the development of brown tides. That is, even under similar (and apparently optimal) conditions, brown tides do not always result, or bloom development stalls for unknown reasons. Whether or not A. anophagefferens dominates in a particular phytoplankton assemblage may be sensitive to the duration of very specific environmental/biological conditions (Caron et al. in press). Subtle changes in nutrient availability or zooplankton composition and feeding activity that were not apparent at our level of examination must be responsible for this variability. This interpretation is consistent with the 'open niche' concept of Smayda \& Villareal (1989), according to which dramatic changes in dominance of the phytoplankton assemblage can occur as a consequence of changes in chemical, physical or biological parameters that are subtle and difficult to resolve. Thus, the presence of the submersible pumps in our experiments did not specifically and consistently cause brown tides but it did set up initial conditions that, in most cases, allowed more rapid net growth rate of the brown tide alga relative to other algal species.

\section{Mercenaria mercenaria and the prevention of brown tides}

The ability of the pumps to promote blooms of the brown tide alga in our mesocosms provided us with a powerful experimental tool to directly compare the importance of Mercenaria mercenaria for preventing these events. Direct comparisons were made in mesocosms set up to induce brown tide development with mesocosms treated exactly the same way but with $M$. mercenaria present from the beginning of the experiment.

It is noteworthy that the clearance rates of clams in Expt 1 were severely reduced when placed into mesocosms in which Aureococcus anophagefferens had already bloomed (Fig. 4). Clearance rates in the mesocosms with low abundances of the brown tide alga were more than 1 order of magnitude greater than rates for clams transferred into mesocosms with high abundances of the alga. Once the bloom had become established, the clams were not able to significantly impact the phytoplankton assemblage and we suspect that feeding was curtailed due to the adverse effect of $A$. anophagefferens on this process (Tracey 1988, Tracey et al. 1988, Bricelj \& Kuenstner 1989, Bricelj et al. 2001).

In contrast, the presence of high abundances of northern quahogs (19 per mesocosm; Fig. 1) present at the beginning of Expt 1 greatly affected phytoplankton biomass and community structure. Similarly, the effect of 8 or 16 Mercenaria mercenaria in each mesocosm of Expts 2 and 3 (Nutrients + Pump + 8 clams and Nutrients + Pump +16 clams treatments) had dramatic effects on the concentration of chl $a$, the absolute and relative abundances of Aureococcus anophagefferens, and the abundances of microplankton and mesozooplankton. Overall, these differences in the phytoplankton and zooplankton indicated that high abundances of clams maintained strong grazing control in the mesocosms. Based on the observed clam clearance rates and the water volume in the mesocosms, turnover times of the water in the mesocosms of 0.51 to $1.6 \mathrm{~d}$ were sufficient to maintain strong top-down control of the pelagic food web including the growth of $A$. anophagefferens. 
The specific mechanism by which Mercenaria mercenaria restrains net population growth of Aureococcus anophagefferens in these mesocosms is not clear. Capture efficiencies of particles the size of the brown tide alga ( 2 to $4 \mu \mathrm{m}$ ) are less than the capture efficiencies for larger particles (Dame 1996, Bricelj et al. 2001). However, the maximal intrinsic growth rate of $A$. anophagefferens does not appear to be particularly fast (Cosper et al. 1993, Gobler \& Cosper 1996, Gobler \& Sañudo-Wilhelmy 2001, Caron et al. in press) and thus even modest removal rates might be sufficient to have a significant effect on net population growth of the alga.

Increases in chl a concentration and the absolute and relative abundance of Aureococcus anophagefferens in the mesocosms with 2 clams were comparable to changes in these parameters in the mesocosms without clams (Nutrients + Pump and Nutrients + Pump +2 clams treatments in Figs. 5 and 8). That is, the presence of 2 clams had no noticeable effect on the accumulation of phytoplankton or A. anophagefferens relative to results in the comparable treatment without clams. In fact, maxima in these parameters during the 2 experiments were greater for the Nutrients + Pump +2 clams treatment than for the nutrient enriched treatment without pumps (Nutrients treatment). Total clearance rates for this treatment in the 2 experiments (3.6 and $13 \mathrm{~d}$ in Expts 2 and 3, respectively) were insufficient to maintain control over phytoplankton biomass in general and $A$. anophagefferens specifically.

Results for mesocosms with 4 clams differed somewhat between Expts 2 and 3. Chl a, Aureococcus anophagefferens and larger zooplankton abundances remained low in the Nutrients + Pump + 4 clams treatment during Expt 2 (Figs. 3b and 5) and generally similar to the treatments with 8 or 16 clams. On the contrary, these parameters increased markedly in the Nutrients + Pump +4 clams treatment during Expt 3 (albeit somewhat more slowly than treatments with 2 clams or no clams; Figs. 3c and 8). Total clearance rates measured for this treatment corresponded to turnover times for the water in the mesocosms of 2.4 (Expt 2) and $9.0 \mathrm{~d}$ (Expt 3).

Based on these results, we conclude that the minimal abundance of Mercenaria mercenaria required to prevent a substantial increase in phytoplankton biomass and a brown tide must be sufficient to maintain a turnover time for the water in the mesocosms of 2 to $3 \mathrm{~d}$. The exact abundance of $M$. mercenaria required to bring about this control in our experiments is, of course, dependent on the specific conditions of our setup (e.g. mixing, nutrient enrichment). All mesocosms in our experiments received daily additions of phytoplankton nutrients that are probably in excess of nutrient loading typically experienced in coastal lagoons. Abundances of pelagic microbial herbivores (e.g. phagotrophic protists, many crustacea) will also vary from abundances observed in our mesocosms, and their contribution to total phytoplankton consumption must be considered. Nevertheless, our experimental results do provide a benchmark for estimating the abundances of $M$. mercenaria that might be necessary to bring about a similar control of phytoplankton assemblages in a natural setting.

The clam abundances employed in our mesocosms spanned a range that encompassed strong control of phytoplankton and prevention of brown tides (treatments with 8,16, 19 clams) to abundances that showed a complete lack of control of phytoplankton biomass (Nutrients + Pump +2 clams treatment in Expts 2 and $3)$. Intense brown tides developed in the latter treatment. The result differed for the Nutrients + Pump +4 clams treatment in Expts 2 and 3. Clearance rates in the treatments in which brown tides did not develop corresponded to turnover times of the water in the mesocosms due to clam filtration ranging from 0.51 to $2.4 \mathrm{~d}$, while clearance rates in the treatments in which brown tides did develop corresponded to turnover times of 3.7 to $25 \mathrm{~d}$. Interestingly, these 2 ranges of turnover times are similar to estimates calculated for the impact of Mercenaria mercenaria grazing in Great South Bay in the 1970s (prior to brown tides) and 1990s (Kassner 1993). That study calculated that feeding activities by this species in the 1970s constituted a turnover time for the volume of Great South Bay of $2.6 \mathrm{~d}$ based on landings, while the same calculation in the 1990s indicated a turnover time of 10 to $25 \mathrm{~d}$. While not conclusive, the similarity between these sets of numbers is striking given that brown tides in these waters first appeared in 1985.

\section{Conclusion}

Suspension-feeding bivalve molluscs play major roles in the biological processes of shallow ecosystems (Officer et al. 1982, Sullivan et al. 1991, Ulanowicz \& Tuttle 1992). These species exert a direct influence on phytoplankton assemblages through their feeding activities and may also affect these assemblages indirectly by altering the abundance and species composition of pelagic microbial grazers (Threlkeld 1988). In addition, bivalves can affect the nature and flux of inorganic and organic compounds from the sediments (Smaal \& Prins 1993) and thus, alter rates of primary production, nutrient availability and nutrient competition among phytoplankton in the water above these benthic assemblages (Doering et al. 1986, Riemann et al. 1988, Sullivan et al. 1991).

Our experimental studies of the role of northern quahog Mercenaria mercenaria have indicated that 
this suspension-feeding bivalve may play a pivotal role in controlling outbreaks of brown tides caused by Aureococcus anophagefferens in the shallow estuaries of Long Island, New York. The brown tide alga in our nutrient-enriched mesocosms without clams attained abundances comparable to abundances observed in nature during severe brown tides $\left(>1 \times 10^{6} \mathrm{cells}^{-1}\right)$. In contrast, mesocosms treated in the same manner but with $M$. mercenaria present at abundances that resulted in clearance rates equivalent to turnover times of 0.51 to $2.4 \mathrm{~d}$ showed no increase in phytoplankton biomass or, remarkably, in the relative abundance of A. anophagefferens among the phytoplankton species in the mesocosms. We conclude that restoration of these bivalve assemblages may constitute a feasible mechanism for improving water quality and preventing brown tides in the shallow, pelagic ecosystems that characterize the coastal waters of Long Island.

Acknowledgements. We gratefully acknowledge the support of G. Rivara and K. Tetrault, and the personnel of the Suffolk County Marine Environmental Learning Center for providing facilities and space for conducting the field experiments. Assistance with the field experiments was provided by $\mathrm{M}$. Pikhar, R. Marzec and D. Greenfield, and for zooplankton enumeration by E. Hillebrand. This research was supported by New York Sea Grant (grant No. R/CMB-23). This is contribution number 1292 from Marine Sciences Research Center of Stony Brook University.

\section{LITERATURE CITED}

Andersen RA, Saunders GW, Paskind MP, Sexton JP (1993) Ultrastructure and 18S rRNA gene sequence for Pelagomonas calceolata gen. et sp. nov. and the description of a new algal class, the Pelagophyceae classis nov. J Phycol 29:701-715

Anderson DM (1989) Toxic algal blooms and red tides: a global perspective. In: Okaichi T, Anderson DM, Nemoto $\mathrm{T}$ (eds) Red tides: biology, environmental science, and toxicology. Elsevier, New York, p 11-16

Anderson DM (1997) Turning back the harmful red tide. Nature 388:513-514

Anderson DM, Garrison DJ (1997) The ecology and oceanography of harmful algal blooms. Limnol Oceanogr 42(5:2): 1009-1305

Arar EJ, Collins GB (1992) In vitro determination of chlorophyll $a$ and pheophytin a in marine and freshwater phytoplankton by fluorescence. In: Method U (ed) Methods for the determination of chemical substances in marine and estuarine environmental samples. USEPA Cincinnati, $\mathrm{OH}, \mathrm{p} 445$

Berg GM, Glibert PM, Lomas MW, Burford MA (1997) Organic nitrogen uptake and growth by the chrysophyte Aureococcus anophagefferens during a brown tide event. Mar Biol 129:377-387

Bricelj VM, Kuenstner SH (1989) Effects of the 'brown tide' on the feeding physiology and growth of bay scallops and mussels. In: Cosper EM, Bricelj VM, Carpenter EJ (eds) Novel phytoplankton blooms: causes and impacts of recurrent brown tides and other unusual blooms, SpringerVerlag, Berlin, p 491-509
Bricelj VM, Lonsdale DJ (1997) Aureococcus anophagefferens: causes and ecological consequences of brown tides in U.S. Mid-Atlantic coastal waters. Limnol Oceanogr 42: 1023-1038

Bricelj VM, Malouf RE (1984) Influence of algal and suspended sediment concentrations on the feeding physiology of the hard clam, Mercenaria mercenaria. Mar Biol 84: 155-165

Bricelj VM, MacQuarrie SP, Schaffner RA (2001) Differential effects of Aureococcus anophagefferens isolates ('brown tide') in unialgal and mixed suspensions on bivalve feeding. Mar Biol 139:605-615

Burkill PH, Mantoura RFC, Llewellyn CA, Owens NJP (1987) Microzooplankton grazing and selectivity of phytoplankton in coastal waters. Mar Biol 93:581-590

Buskey EJ, Montagna PA, Amos AS, Whitledge TE (1997) Disruption of grazer populations as a contributing factor to the initiation of the Texas brown tide algal bloom. Limnol Oceanogr 42:1215-1222

Caron DA, Schaffner RA, Moran DM, Dennett MR, Lonsdale DJ, Gobler CJ, Nuzzi R, McLean TI (2003) Development and application of a monoclonal antibody for counting Aureococcus anophagefferens, an alga causing recurrent brown tides in the northeastern United States. Appl Environ Microbiol 69:5492-5502

Caron DA, Gobler CJ, Lonsdale DJ, Cerrato RM and 6 others (in press) Microbial herbivory on the brown tide alga, Aureococcus anophagefferens: results from natural ecosystems, mesocosms and laboratory experiments. Harmful Algae

Cerrato RM, Wallace HVE (1989) Population dynamics of the hard clam: a statistical anaalysis based on existing Town of Brookhaven survey data. Spec Rep 84, Marine Sciences Research Center, State University of New York, Stony Brook, NY

Cosper EL, Carpenter ES, Cottrell M (1989a) Primary productivity and growth dynamics of the 'brown tide' in Long Island embayments. In: Cosper EL, Bricelj VM, Carpenter ES (eds) Novel phytoplankton blooms: causes and impacts of recurrent brown tides and other unusual blooms. Springer-Verlag, New York, p 139-158

Cosper EM, Carpenter EJ, Cottrell M (1989b) An examination of the environmental factors important in initiating and sustaining 'brown tide' blooms. In: Cosper EM, Bricelj VM, Carpenter ES (eds) Novel phytoplankton blooms: causes and impacts of recurrent brown tides and other unusual blooms. Springer-Verlag, New York, p 317-340

Cosper EM, Garry RT, Milligan AJ, Coall MH (1993) Iron, selenium and citric acid are critical to the growth of the 'brown tide' microalga, Aureococcus anophagefferens. In: Smayda GJ, Shimizu Y (eds) Toxic phytoplankton blooms in the sea. Elsevier Science Publishers, New York, p 667-673

Coughlan J (1969) The estimation of filtering rate from the clearance of suspensions. Mar Biol 2:356-358

Dame RF (1996) Ecology of marine bivalves: an ecosystem approach. CRC Press, Boca Raton, FL

Dennison WC, Marshall GJ, Wigand C (1989) Effect of 'brown tide' shading on eelgrass (Zostera marina L.) distribution. In: Cosper EM, Bricelj VM, Carpenter EJ (eds) Novel phytoplankton blooms: causes and impacts of recurrent brown tides and other unusual blooms. Springer-Verlag, Berlin, p 675-692

Doering PH, Oviatt CA, Kelly JR (1986) The effects of the filter-feeding clam Mercenaria mercenaria on carbon cycling in experimental marine mesocosms. J Mar Res 44: 839-861 
Flynn KJ, Davidson K, Cunnigham A (1996) Prey selection and rejection by a microflagellate; implications for the study and operation of microbial food webs. J Exp Mar Biol Ecol 196:357-372

Gainey LF Jr, Shumway SE (1991) The physiological effect of Aureococcus anophagefferens ('brown tide') on the lateral cilia of bivalve mollusks. Biol Bull (Woods Hole) 181: 298-306

Gobler CJ (1995) The role of iron in the occurrence of Aureococcus anophagefferens blooms. MS thesis, State University of New York at Stony Brook

Gobler CJ, Cosper EM (1996) Stimulation of 'brown tide' blooms by iron. In: Yasumoto $\mathrm{T}$, Oshima $\mathrm{Y}$, Fukuyo $\mathrm{Y}$ (eds) Harmful and toxic algal blooms. Intergovernmental Oceanographic Commission, UNESCO, Paris, p 321-324

Gobler CJ, Sañudo-Wilhelmy SA (2001) Effects of organic carbon, organic nitrogen, inorganic nutrients and iron additions on the growth of phytoplankton and bacteria during a brown tide bloom. Mar Ecol Prog Ser 209:19-34

Gobler CJ, Renaghan MJ, Buck NJ (2002) Impacts of nutrients and grazing mortality on the abundance of Aureococcus anophagefferens during a New York brown tide bloom. Limnol Oceanogr 47:129-141

Griffin SL, Rippingale RJ (2001) Zooplankton grazing dynamics: top-down control of phytoplankton and its relationship to an estuarine habitat. Hydrol Processes 13:2453-2464

Jürgens K, Demott WR (1995) Behavioral flexibility in prey selection by bactivorous flagellates. Limnol Oceanogr 40 1503-1507

Kassner J (1993) Possible effects of reduced hard clam abundance in Great South Bay. On the Water July/Aug:4-5. Cornell Cooperative Extennsion of Suffolk County, Riverhead, NY

LaRoche J, Nuzzi R, Waters R, Wyman K, Falkowski PG, Wallace WR (1997) Brown tide blooms in Long Island's coastal waters linked to interannual variability in groundwater flow. Global Change Biol 3:397-410

Liu H, Buskey EJ (2000) The exopolymer secretions (EPS) layer surrounding Aureoumbra lagunensis cells affects growth, grazing, and behavior of protozoa. Limnol Oceanogr 45:1187-1191

Lomas MW, Glibert PM, Berg GM, Burford M (1996) Characterization of nitrogen uptake by natural populations of Aureococcus anophagefferens (Chrysophyceae) as a function of incubation duration, substrate concentration, light, and temperature. J Phycol 32:907-916

Newell RIE (1988) Ecological changes in Chesapeake Bay: are they the result of overharvesting the Eastern oyster (Crassostrea virginica)? In: Lynch MP, Krome EC (eds) Understanding the estuary: advances in Chesapeake Bay research. Publication 1129 (CBP/TRS 24/88), Chesapeake Research Consortium, Gloucester Point, VA, p 536-546

Officer CB, Smayda TJ, Mann R (1982) Benthic filter feeding: a natural eutrophication control. Mar Ecol Prog Ser 9:203-210

Riemann B, Nielsen TG, Horsted SJ, Bjornsen PK, Pock-Steen $\mathrm{J}$ (1988) Regulation of phytoplankton biomass in estuarine enclosures. Mar Ecol Prog Ser 48:205-215

Schaffner RA (1999) The role of suspension feeding bivalves in the initiation and control of Aureococcus anophagefferens blooms. MS thesis, State University of New York, Stony Brook, NY

Editorial responsibility: Otto Kinne (Editor), Oldendorf/Luhe, Germany
Sherr EB, Sherr BF (1993) Preservation and storage of samples for enumeration of heterotrophic protists. In: Kemp PF, Sherr BF, Sherr EB, Cole JJ (eds) Handbook of methods in aquatic microbial ecology. Lewis Publishers, Boca Raton, FL, p 207-212

Sieburth JM, Johnson PW, Hargraves PE (1988) Ultrastructure and ecology of Aureococcus anophagefferens gen. et sp. nov. (Chrysophyceae): the dominant picoplankter during a bloom in Narragansett Bay, Rhode Island, summer 1985. J Phycol 24:416-425

Smaal AC, Prins TC (1993) The uptake of organic matter and the release of inorganic nutrients by bivalve suspension feeder beds. In: Dame RF (ed) Bivalve filter feeders in estuarine and coastal ecosystem processes. SpringerVerlag, Berlin, p 271-298

Smayda TJ (1989) Primary production and the global epidemic of phytoplankton blooms in the sea: a linkage? In: Cosper EM, Bricelj VM, Carpenter EJ (eds) Novel phytoplankton blooms: causes and impacts of recurrent brown tide and other unusual blooms. Springer-Verlag, Berlin, p 449-483

Smayda TJ, Villareal TA (1989) The 1985 'brown tide' and the open phytoplankton niche in Narragansett Bay during summer. In: Cosper EM, Bricelj VM, Carpenter EJ (eds) Novel phytoplankton blooms: causes and impacts of recurrent brown tides and other unusual blooms. SpringerVerlag, Berlin, p 159-187

Stoecker DK, Cucci TL, Hulburt EM, Yentsch CM (1986) Selective feeding by Balanion sp. (Ciliata: Balanionidae) on phytoplankton that best support its growth. J Exp Mar Biol Ecol 95:113-130

Stoecker DK, Gifford DJ, Putt M (1994) Preservation of marine planktonic ciliates: losses and cell shrinkage during fixation. Mar Ecol Prog Ser 110:293-299

Strom SL, Loukos H (1998) Selective feeding by protozoa: model and experimental behaviors and their consequences for population stability. J Plankton Res 20:831-846

Sullivan BK, Doering PH, Oviatt CA, Keller AA, Frithsen JB (1991) Interactions with the benthos alter pelagic food web structure in coastal waters. Can J Fish Aquat Sci 48: $2276-2284$

Threlkeld ST (1988) Planktivory and planktivore biomass effects of zooplankton, phytoplankton, and the trophic cascade. Limnol Oceanogr 33:1362-1375

Tracey GA (1988) Feeding reduction, reproductive failure, and mortality in Mytilus edulis during the 1985 'brown tide' in Narragansett Bay, Rhode Island. Mar Ecol Prog Ser 50:73-81

Tracey GA, Johnson PW, Steele RW, Hargraves PE, Sieburth JM (1988) A shift in photosynthetic picoplankton composition and its effect on bivalve mollusc nutrition: the 1985 'brown tide' in Narragansett Bay, Rhode Island. J Shellfish Res 7:671-675

Ulanowicz RE, Tuttle JH (1992) The trophic consequences of oyster stock rehabilitation in Chesapeake Bay. Estuaries 15:298-306

Utermöhl H (1958) Zur Vervollkommnung der quantitativen Phytoplankton-Methodik. Mitt Int Ver Limnol 9:1-38

Wiadnyana NN, Rassoulzadegan F (1989) Selective feeding of Acartia clausi and Centropages typicus on microzooplankton. Mar Ecol Prog Ser 53:37-45

Submitted: June 30, 2003; Accepted: June 22, 2004

Proofs received from author(s): October 19, 2004 